\title{
The Management of Elimination Train Delays and Socio-Economic Impacts in Slovak Conditions
}

\author{
Juraj Camaj \\ Faculty of Operation and Economics of Transport and \\ Communication, University of Zilina \\ Zilina, Slovakia \\ juraj.camaj@fpedas.uniza.sk
}

\author{
Jozef Danis \\ Faculty of Operation and Economics of Transport and \\ Communication, University of Zilina \\ Zilina, Slovakia \\ jozef.danis@fpedas.uniza.sk
}

\author{
Anna Dolinayova \\ Faculty of Operation and Economics of Transport and Communication, University of Zilina \\ Zilina, Slovakia \\ anna.dolinayova@fpedas.uniza.sk
}

\begin{abstract}
Within the framework of the common transport policy is the quality of rail transport services and customer satisfaction with the services very important. Currently, customers are more educated and increasingly demand higher quality and in the case of unfulfilled requirements they expect compensation. Insufficient quality has a significant impact in terms of railway sector costs.

One of the main key factors in construction the quality and competitive rail transport is a punctuality of trains. It is measured by comparing the planned time schedule of a train with its identification number and the actual driving time.

The paper is aimed at assessing the possibility of eliminating delays of the passenger trains in conditions of Slovakia. These delays are eliminated by the introduction of a compensation mechanism between the railway passenger operator and the infrastructure manager. The fee helps to accurate monitoring and elimination of the reasons of delays. It is also incorporated an element of regional disparities, where the amount of compensatory fee is determined based on the type of train and its final destination.
\end{abstract}

Keywords - train delay, compensation fee, passenger transport

\section{INTRODUCTION}

Regional disparities are affected by external cultural influences, regulations of state, rate of urbanization, industrialization, as well as differences in demographic trends, the level of education, environmental quality, economic productivity and other factors. [4]

Significant effect on the further development of the Regions has the quality of transport services. The specific situation of has a railway passenger transport. This type of service can accurately quantify the size of delay in terms of delays and also the reasons for the delay. In the event of delay, each passenger has the right to compensation. But also train delays have some reasons. It is therefore possible, on the grounds of delay to determine whether the compensation method among all stakeholders in the transport chain, taking into account the regional differences. The paper is aimed at assessing the possibility of eliminating delays of passenger trains in conditions of Slovakia. [6] These delays are eliminated by the introduction of a compensation mechanism between the railway passenger operator and the infrastructure manager. The fee helps to accurate monitoring and elimination of the reasons of delay. It is also incorporated an element of regional disparities, where the amount of compensatory fee is determined based on the type of train and its final destination.

\section{CHARACTERISTICS OF THE TRAIN OF PASSENGER TRANSPORT}

Passenger trains in particular ensure carriage of passengers, baggage and courier shipments. These trains are built mainly of passenger railway carriages and certain types of train also of wagons for the carriage of mail or wagons for car. [5, 8]

In the conditions of The Slovak Republic are trains divided into four main groups and subgroups: [2, 7]

- The Express trains (Ex) - SuperCity (SC), EuroCity (EC), EuroNight (EN), InterCity (IC), Expres (Ex). Express trains are trains of the highest quality and they are characterized in that connecting the significant places at the regional and national long distance. They are operating at national and international level.

- The Fast trains (Ft) - Fast train (Ft), Regional Fast train (RFt), Regional Express (REX), EuroRegio (ER). The fast trains are trains designed for quick transportation over longer distance. These trains stop only at important stations in view of passenger transport. They operate mainly at national level.

- Passenger train (Pt) - Through train (Tt), Passenger train (Pt), Passenger trains are trains with the lowest category and are intended for passenger transport to all stops and stations. These trains have a lower priority than the importance of Express and Fast trains. They are most often compiled only with 2nd class wagons. 
- Service train (St) - The service train are designed for moving train sets from final stations to another originating stations according to the internal regulations.

\section{REGIONAL DISPARITIES AND SOCIO-ECONOMIC INDICATORS IN SLOVAKIA}

Regional disparities are differences in the socio-economic development of regions that are the result of irregularities. For analysis of regional disparities are used the various methods: the Gini index (GI), coefficient of variation (CV), Theil index, cluster analysis, etc. The Gini coefficient is usually defined mathematically based on the Lorenz curve, which plots the proportion of the total income of the population (y axis) that is cumulatively earned by the bottom $\mathrm{x} \%$ of the population (see diagram). The line at 45 degrees thus represents perfect equality of incomes. The Gini coefficient can then be thought of as the ratio of the area that lies between the line of equality and the Lorenz curve (marked A in the diagram) over the total area under the line of equality (marked $\mathrm{A}$ and $\mathrm{B}$ in the diagram): $[4,6]$

The value of the Gini coefficient may vary from 0 (perfect equality when all households receive the same income) to 1 (perfect inequality when one household earns the total income in a country). Slovak Republic has reached Gini coefficient of about 0.27 , which is below the OECD average (0.31).

Factors for determining the socio-economic indicators in Slovakia:

- Regional Gross Domestic Product (RGDP)

- Unemployment

- Jobseekers

- The average monthly wage of employees

- The net cash income of households

\section{TRAINS DELAYS CLASSIFICATION}

Train delays are caused by reasons that can be divided into three categories. The first category is made up the delay caused from the infrastructure manager. The second category contains culpable delay by the railway operators. The third category includes external reasons (landslide, floods) and secondary delay. If the train is delayed over the specified limit, it is responsible for the delay the party that caused the largest share of train delays. [1, 2, 7]

The agreement includes a code table that is clearly divided and given responsibility of the infrastructure manager and railway operators. The code table is formed by nine groups consisting in each group a number of sub-groups (up to ten).

The delay is monitored only on the rail network of Slovak Railways in international trains are delayed tracks where the rail network was established Slovak railways. Subsequent delays encoding is performed by coders' delays, based on UIC 450-2 which is valid for all members of UIC. [8] The result of this decree is to establish a uniform coding system to determine the causes of delays and denial of services. Additionally, it establishes uniform procedures and methods for recording, transmitting and analyzing information itself. The basic code table is divided according to the originator of responsibility for the delay in two parts and the errors incurred by the infrastructure manager and the RU. [1, 5] It contains nine groups and up to ten several subgroups by cause delays. The first four groups are the causes of delays on the part of the infrastructure manager. Another part table summarizes the causes of delays caused by railway operator. It is made up of three groups and several subgroups. External causes beyond its control railway operator or infrastructure manager are described in the eighth group. The ninth group dealing with secondary causes, which include hazardous incidents, accidents and risks. These events are in fact the primary causes, but in many they cannot be held liable in the short term. [7]

\section{ANALYSIS OF PASAGERS TRAIN DELAYS ON THE NETWORK OF SLOVAK RAILWAYS}

Result of analysis based on statistics collected of delays on passenger trains in 2015 broken down by causes of delays. Each one has its cause and responsible party code corresponding to a given cause. Total time delay of all of trains in 2014 enrolled in each code is 2106921 minutes and the number of delays is the 600513 for the year 2015, it failed to detect the height of the global increase of delay in minutes and the causes of delays between the parties. For that reason was the base year used for the calculation of 2015. [3]

The overall proportion of organizations to delay of passenger trains is given in Table 1.

TABLE I. PERCENTUAL SHARE OF TRAIN DELAYS [3]

\begin{tabular}{|c|c|c|}
\hline & \multicolumn{2}{c|}{ Share in \% } \\
\hline It Caused delays & Number of cases & Minutes \\
\hline Railway operator & $21,36 \%$ & $13,47 \%$ \\
\hline Unspecified & $50,48 \%$ & $68,25 \%$ \\
\hline Infrastructure Manger & $28,17 \%$ & $18,29 \%$ \\
\hline Total & $100,00 \%$ & $100,00 \%$ \\
\hline
\end{tabular}

\section{THE MODEL OF COMPENSATION SYSTEM FOR TRAIN DELAYS}

The amount of compensation is determined on the basis of the actual delay on passenger trains. In fact, the difference between the regular arrival of the train in accordance with the timetable and the actual arrival of transport so called monitoring points, i.e. the arrival station. Responsible entity that has caused the highest increase of delay irrespective of the amount of delay at intermediate stations pay the calculated amount of compensation. [1]

Fees for compensation apply to all categories of domestic and international passenger trains. For international trains, the amount of delay monitors only for Slovak Railways network. Start tracking the train begins at the moment of entry into the network of Slovak railways, and to crossing or stopping at the entrance border crossing stations. End monitoring train terminates at the moment of transition or departure of a train from the exit border crossing stations. Delays which caused foreign railway administration does not include the compensation system for entering into railway administration. 
For all types of trains are fixed threshold of 5 minutes, in which the train is believed to be accurate and without compensation. The main objective of model compensation system is to determine the amount of tax per minute increase of delay beyond the specified threshold. The model has a linear evaluation system delays. It based on the evaluation of one minute delay. $[2,5]$

To determine the amount of influence of impact for railway operators and infrastructure managers linear model was designed solutions based on the overall achievement of revenues from charging for the use of railway infrastructure. The calculation of the compensation fee is derived from the total revenues generated from the payment of the minimum access package and track access to service facilities and the overall increase in the delay in minutes per year. [2] Development of revenues from the fee for access to infrastructure is reported in Table 2.

TABLE II. SALES DEVELOPMENT FROM THE FEE FOR ACCESS TO RAILWAY INFRASTRUCTURE [3, 7]

\begin{tabular}{|c|c|c|}
\hline Year & $\begin{array}{c}\text { Total receipts from the fee for } \\
\text { access to railway infrastructure }\end{array}$ & $\begin{array}{c}\mathbf{1 \%} \text { of the receipts from the fee } \\
\text { for access to railway } \\
\text { infrastructure }\end{array}$ \\
\cline { 2 - 3 } & $\boldsymbol{\epsilon}$ & $\boldsymbol{€}$ \\
\hline $\mathbf{2 0 1 3}$ & 43415000 & 434150 \\
\hline $\mathbf{2 0 1 4}$ & 44321000 & 443210 \\
\hline $\mathbf{2 0 1 5}$ & 45892000 & 458920 \\
\hline
\end{tabular}

When sales from the fee for access to the rail network total is considered the level of sales in 2015. [4]

Calculation of the rate per minute of delay on the basis that determines the amount of delay compensation, based on one percent of the total revenues earned from payment of the minimum access package and track access to service facilities in 2014 and the overall increase in delays breakdown of reasons for the delay. [3]

On the basis input data from 2015 was calculated the rate by the equation:

$$
R_{L}=\frac{V_{T}^{Y}}{T_{T}^{Y}}(€ / \min )
$$

where:

$R_{L}$ - rate for linear model ( $\left.€ / \mathrm{min}\right)$,

$V_{T}^{Y}$ - one percent of the total revenues (in a particular year) earned from payment of the minimum access package and track access to service facilities $(€)$,

$T_{T}^{Y}$ - the overall increase delays Infrastructure Manager and Railway Operators (min) (in a particular year).

The amount of increase delay due to the infrastructure manager and the Railway Operators are 838,633 minutes in 2014, based on the table no. 3 and a value of one percent of sales based on Table 2. These values were fit to the following equation (1):

$$
R_{L}=\frac{V_{T}^{2015}}{T_{T}^{2015}}=\frac{458920}{838671}=0,547(€ / \mathrm{min})
$$

The rate of the compensation fee of linear compensation system for all passenger trains per year 2015 is $0,547 € / \mathrm{min}$.

\section{THE FINANCIAL IMPACT OF THE PROPOSAL MODEL COMPENSATION SYSTEM}

First it was necessary to obtain the percentage distribution of the total increase delays in minutes divided by fixed intervals to determine the amount of impact for stakeholders. It starting with the percentage split of 2015 to determine the amount of the impact between the stakeholders.

Calculate the overall impact of introducing the delay compensation are shown in Table 3. Delays caused by the infrastructure manager are calculated separately. Likewise, the fee for the delay caused by the railway operators is calculated separately. The total balance consists the amount of compensation to be paid by infrastructure manager.

\begin{tabular}{|c|c|c|c|c|c|c|c|c|c|}
\hline & & \multicolumn{6}{|c|}{ Intervals } & \multirow[b]{2}{*}{$\begin{array}{c}\text { Summary } \\
\text { [min] }\end{array}$} & \multirow{2}{*}{$\begin{array}{c}\text { Costs } \\
{[€]}\end{array}$} \\
\hline & & $\begin{array}{c}6-15 \\
{[\mathrm{~min}]}\end{array}$ & $\begin{array}{l}16-30 \\
{[\mathrm{~min}]}\end{array}$ & $\begin{array}{l}31-60 \\
{[\mathrm{~min}]}\end{array}$ & $\begin{array}{c}\text { 61-120 } \\
\text { [min] }\end{array}$ & $\begin{array}{c}121-240 \\
{[\mathrm{~min}]}\end{array}$ & $\begin{array}{c}\text { over } 240 \\
\text { [min] }\end{array}$ & & \\
\hline \multicolumn{2}{|c|}{ percentage of delays } & $25,29 \%$ & $9,50 \%$ & $5,29 \%$ & $4,19 \%$ & $2,64 \%$ & $7,01 \%$ & & \\
\hline Infrastructure manager & 547633 & 138496 & 52025 & 28970 & 22946 & 14458 & 38389 & 295284 & 155910 \\
\hline Railway operators & 291038 & 73604 & 27649 & 15396 & 12194 & 7683 & 20402 & 156928 & 82858 \\
\hline Balance & 244872 & 64893 & 24377 & 13574 & 10751 & 6774 & 17987 & 138356 & 73052 \\
\hline
\end{tabular}

TABLE III. DETERMINING THE AMOUNT OF THE IMPACT BETWEEN STAKEHOLDERS [3]

Based on the assigned delay the increase in each interval we obtain a total redistribution of delay increases above a threshold that are processed in the compensation model.

To determine the amount of impact we need to determine the amount of the fees incurred by the parties concerned.
According to the overall balance is determined by the different parties to set fee under the compensation scheme. Determining amount of costs for delay shall be calculated by the equation:

$$
C_{s}=\sum T_{I} * R_{L}
$$


where:

$C_{s}$ - the cost of the responsible subject (MI, RO) of the total increase delay $(€)$

$T_{I}$ - the total delay in minutes above a certain threshold (min)

$R_{L}$ - the rate $(€ / \mathrm{min})$,

Following the calculation of total compensation for the causes of delays stakeholders followed the overall balance of compensation and evidence of impact according to the equation:

$$
C=C_{M I}-C_{R O}
$$

where:

$C$ - amount of compensation to be paid (€)

$C_{M I}$ - the total compensation paid to infrastructure managers for the year $(€)$

$C_{R O}$ - the total compensation paid to railway operator for the year $(€)$

Figure 1 shows the total compensation under the responsibility for the delay and the overall balance of the infrastructure manager in view of the introduction of the compensation scheme.

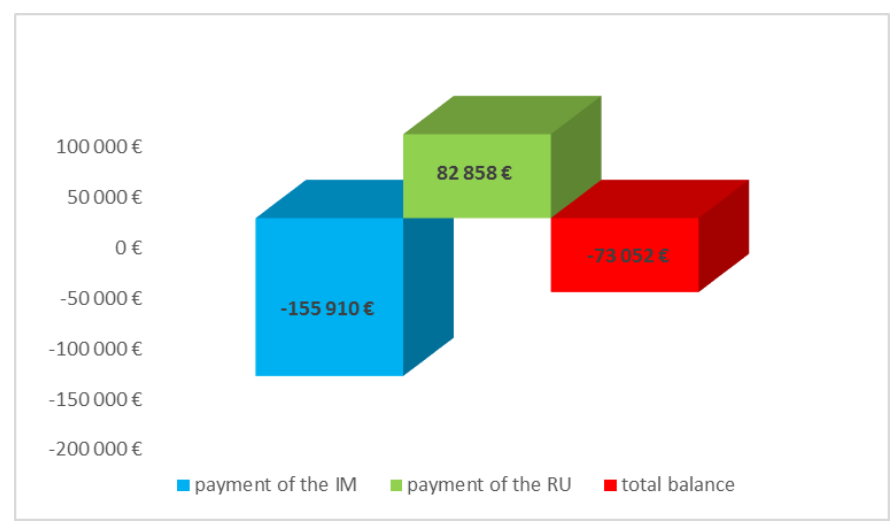

Fig. 1. Total compensation under the responsibility of the overall balance of view of the IM.

\section{VIII.OPTIONS TO SOLVE COMPENSATION MECHANISM AFTER TAKING INTO ACCOUNT THE REGIONAL DISPARITIES}

Each passenger trains has its target station where passengers ending their trip and go to work or transfer onto another train to the final destination of their journey. Therefore, evaluation of train delays should be implemented according to the final destination at a particular train and follow-up joints in intended station. [2,4]

Application of the general model solutions compensatory mechanism in Slovak condition after adding the Gini index as mentioned aggregate indicators of regional disparities we achieve balance those compensatory mechanism.

\section{CONCLUSION}

The result of compensation model is proposed methodologies heights rate per minute increase of delay. In addition, it is necessary to sensitively determine the amount of the threshold with respect to the operating conditions. Respecting the minimum threshold, the trains will be considered accurate and not incorporated to the compensation system. Finally, the impacts are calculated in view of the infrastructure manager.

For determining the amount of compensatory fees we used data for 2015. The compensatory fees and the overall balance is calculated in view of the infrastructure manager. The total amount of monitored indicators varies according to the height threshold per minute increase delay.

\section{ACKNOWLEDGMENT}

This paper was created within the framework of the following projects:

Project VEGA 1/0095/16 “Assessment of the quality of connections on the transport network as a tool to enhance the competitiveness of public passenger transport system”.

\section{REFERENCES}

[1] Agreement No. 100/2008 relating to common measures to ensure the quality of rail transport operations between infrastructure managers (Železnice Slovenskej republiky) and railway operator (Železničná spoločnost' Slovensko, a.s.). Bratislava: ŽSR, 2008. P.12.

[2] Lalinská, J., Camaj, J., Nedeliaková, E.: Possibilities and solutions of compensation for delay of passenger trains and their economic impacts. In: Transport means 2015 : proceedings of the 19th international scientific conference : Kaunas University of Technology, Lithuania. ISSN 1822-296X. -:pages 729-733.

[3] Internal outputs from Operation information system of infrastructure manager (ŽSR)

[4] Nedeliaková E., Sekulová J., Nedeliak I., Majerčák P.: Services in railway passenger transport and its evaluation by dynamic models. In: Transport means 2014: proceedings of the 18th international conference, Kaunas University of Technology, Lithuania. - ISSN 1822-296X., pages 227-230.

[5] Network statement 2015. Bratislava: Železnice Slovenskej republiky, 2015. Approved by Director General of ŽSR Ref. No.15928/2012 O450. P .56. Available online: http://www.zsr.sk/anglicky/railwaysinfrastructure/marketing/network-statement/network-statement2015.html?page_id=2854

[6] Sekulová J., Nedeliaková E.: Dynamic quality models as a part of quality management system in companies operating railway passenger transport In: Horizons of railway transport 2014. International scientific conference: Strečno, Slovak Republic, September 18th and 19th, 2014. Žilina: Žilinská univerzita, 2014. ISBN 978-80-554-0918-4. - S. 213216.

[7] The annual report of ZSR. Bratislava: Železnice Slovenskej republiky, 2015. P.78. Available online: http://www.zsr.sk/buxus/docs/vyrSpravy/VyrocnaSprava2014.pdf

[8] UIC 450-2:2009 - Assessment of the performance of the network related to rail traffic operation for the purpose of quality analyses - delay coding and delay cause attribution process. 5th edition, June 2009 - ISBN: 9782-7461-1655-9. P.23. Available online: http://www.uic.org/com/IMG/pdf/UIC_Leaflet_450-2.pdf 